\title{
Preparing for the EAC-ABET Visit for a Novel Undergraduate Program in Modeling and Simulation Engineering
}

\author{
Frederic McKenzie, $\mathrm{PhD}{ }^{1}$ \\ ${ }^{1}$ Old Dominion University, USA, rdmckenz@odu.edu
}

\begin{abstract}
Fifty five years ago computer science was just beginning to see common acceptance as a growing discipline and computer science departments were rare at universities although many faculty were utilizing computers and software to enhance their methodologies. This was a similar situation for computer engineering just thirty five years ago. We believe modeling and simulation (M\&S) is on a similar path. Many other disciplines utilize M\&S to enhance their methodologies but we also believe that M\&S fundamentals can be essential in making better decisions by utilizing the appropriate model for the problem at hand, expanding the solution space through simulation, and understanding it through visualization and proper analyses. After our students learn these fundamentals, we offer the opportunity to apply them to varied application areas. This paper shows our efforts to present our case for an ABET accredited M\&S engineering (M\&SE) program.
\end{abstract}

Keywords - simulation, engineering, accreditation

Digital Object Identifier (DOI): http://dx.doi.org/10.18687/LACCEI2015.1.1.098

ISBN: 13 978-0-9822896-8-6

ISSN: 2414-6668

$1^{\text {th }}$ LACCEI Annual International Conference: “Engineering Education Facing the Grand Challenges, What Are We Doing?” July 29-31, 2015, Santo Domingo, Dominican Republic ISBN: 13 978-0-9822896-8-6

ISSN: 2414-6668

DOI: http://dx.doi.org/10.18687/LACCEI2015.1.1.098 


\title{
Preparing for the EAC-ABET Visit for a Novel Undergraduate Program in Modeling and Simulation Engineering
}

\author{
Frederic McKenzie, $\mathrm{PhD}$ \\ Old Dominion University, Norfolk, VA, USA, rdmckenz@odu.edu
}

\begin{abstract}
Fifty five years ago computer science was just beginning to see common acceptance as a growing discipline and computer science departments were rare at universities although many faculty were utilizing computers and software to enhance their methodologies. This was a similar situation for computer engineering just thirty five years ago. We believe modeling and simulation (M\&S) is on a similar path. Many other disciplines utilize M\&S to enhance their methodologies but we also believe that M\&S fundamentals can be essential in making better decisions by utilizing the appropriate model for the problem at hand, expanding the solution space through simulation, and understanding it through visualization and proper analyses. After our students learn these fundamentals, we offer the opportunity to apply them to varied application areas. This paper shows our efforts to present our case for an ABET accredited M\&S engineering (M\&SE) program.
\end{abstract}

Keywords—simulation, engineering, accreditation

\section{INTRODUCTION}

The Bachelor of Science (B.S.) in Modeling and Simulation Engineering (M\&SE) degree program began in 2010 while M\&S programs at the graduate level have existed at ODU since 1998. Because of the significant history of M\&S at ODU, an established cadre of motivated faculty, administrators, and M\&S stakeholders were readily available to draw upon in the establishment of the undergraduate program and the Department.

ODU's sojourn into graduate modeling and simulation programs was initially administered by Dr. Ralph Rogers who, a year earlier, had headed a workshop [1] on the subject while at the Department of Industrial Engineering and Management Systems at the University of Central Florida. His arrival at ODU spurred on the establishment of the first $\mathrm{PhD}$ program in M\&S in the USA in the year 2000 and the first PhD graduate in $M \& S$ in 2003. A year after Dr. Rogers' workshop, teaching $\mathrm{M} \& \mathrm{~S}$ at the undergraduate level was the theme at a 1998 National Science Foundation (NSF) workshop in Vancouver, Canada [2]. Inspiringly, Sarjoughian and Zeigler (2001) broached the subject of teaching $M \& S$ as an undergraduate discipline. Later, in 2006, the NSF Blue Ribbon Panel on Simulation-Based Engineering Science (SBES) [4] stated that "seldom have so many independent studies by experts from diverse perspectives been in such agreement: computer simulation has and will continue to have an enormous impact on all areas of engineering, scientific discovery, and endeavors to solve major societal problems."

Several years after pioneering a successful graduate program and building significant $M \& S$ infrastructure, we became the first in the world M\&S department established specifically to support a B.S. program in the $M \& S$ discipline. Currently, the MSVE Department offers a full spectrum of academic programs. At the undergraduate level, we offer a Bachelor of Science Degree in Modeling and Simulation Engineering and a Minor in M\&S for students majoring in other disciplines. At the graduate level, the Department offers a Graduate Certificate in $M \& S$; Master of Science (thesis option) and Master of Engineering (non-thesis option) Degrees in M\&S; and Doctor of Engineering (practitioner option) and Doctor of Philosophy (research option) Degrees in M\&S.

"Several universities have developed tracks or concentrations focusing on narrow sub-areas of modeling and simulation as part of other degree programs; however, to date, no ABET-accredited engineering program in modeling and simulation has been fully implemented [5]." At the outset, ODU's undergraduate M\&SE program has been designed to meet four sources of program content and goals $[5,6]$ : the general engineering ABET criteria; the $M \& S$ body of knowledge [7, 8]; program-specific student outcomes contributed by MSVE faculty; and university general education requirements. The result is a curriculum that teaches the fundamental principles and theoretical foundations of $M \& S$ and prepares students to enter the workforce as entrylevel engineers or continue graduate study in modeling and simulation as well as other disciplines. M\&SE graduates will also be prepared take the Certified Modeling \& Simulation Professional (CMSP) examination (www.simprofessional.org) and the Engineer in Training (EIT) examination, which serves as a precursor to becoming a Professional Engineer (PE).

\section{MisSION AND EDUCATIONAL OBJeCTIVES}

Old Dominion University's Mission Statement, published in the Old Dominion University Catalog 2013-2014, is quoted below:

Old Dominion University, located in the

City of Norfolk in the metropolitan

$13^{\text {th }}$ LACCEI Annual International Conference: “Engineering Education Facing the Grand Challenges, What Are We Doing?” 
Hampton Roads region of coastal Virginia, is a dynamic public research institution that serves its students and enriches the Commonwealth of Virginia, the nation and the world through rigorous academic programs, strategic partnerships, and active civic engagement.

The mission statement of the Frank Batten College of Engineering and Technology (BCET) is also below:

In accordance with the mission of Old Dominion University, the Frank Batten College of Engineering and Technology promotes the advancement of engineering knowledge, both by its creation and dissemination, and by providing successful graduates and a continuously improving learning environment to its constituents, while maintaining ethical, multicultural and global standards.

The mission statement of the Department of Modeling, Simulation and Visualization Engineering, which is published in the University Catalog and the MSVE website, is as follows:

MSVE serves the public globally with education and research in modeling and simulation through the following:

- Provide high quality undergraduate and graduate modeling and simulation engineering curricula via on-campus and distance learning.

- Conduct cutting edge research in modeling, simulation, and visualization engineering.

- Promote the discipline of modeling and simulation and its use in realworld practical applications

The program educational objectives describe what graduates are expected to attain during the first few years after graduation. The educational objectives of the modeling and simulation engineering program, established with the participation of program constituencies, are consistent with the mission of Old Dominion University and the Department of Modeling, Simulation and Visualization Engineering.

The program educational objectives of the modeling and simulation engineering program are as follows.

Within a few years after graduation, Modeling and Simulation Engineering alumni will have: a) Established themselves as practicing professionals in modeling and simulation engineering or related areas or have engaged in graduate study;

b) Demonstrated their ability to work successfully as members of a professional team and to function effectively as responsible professionals; and,

c) Demonstrated their ability to adapt to changing situations, evolving technologies, and new career challenges.

Program educational objective "a" is consistent with the university's mission of providing rigorous academic programs and BCET's mission of providing successful graduates. Objective " $b$ " is consistent with the ability to form strategic partnerships and once again producing successful graduates. Civic engagement and BCET's mission of a continuously improving learning environment addresses objective "c".

\section{PRogram Constituencies}

The significant constituents of the M\&SE program are

- $\mathrm{M} \& \mathrm{~S}$ engineering faculty

- M\&S alumni

- $\quad$ Employers of M\&S graduates

- Professional and graduate schools that admit M\&S graduates

- The general engineering profession

- The Society for Modeling \& Simulation International (SCS) professional society

All of these groups and individuals are involved in the M\&SE program. The involvement of alumni and employers is via the MSVE Industrial Advisory Board (IAB) and the Virginia Modeling, Analysis and Simulation Center's (VMASC) Industry Association. VMASC conducts technology exchanges between its industry members' researchers and engineers and ODU/VMASC faculty and staff to find common threads in collaborative research and market opportunities. VMASC teams with its industry members on competitive proposals, grants, congressional appropriations proposals and academic research projects. A VMASC industry association (IA) member is a private company which pays annual dues established by the Industry Association Board of Advisors either in cash or in material-in-kind or services. Together, the MSVE IAB and the VMASC IA represent M\&S

$13^{\text {th }}$ LACCEI Annual International Conference: "Engineering Education Facing the Grand Challenges, What Are We Doing?" July 29-31, 2015, Santo Domingo, Dominican Republic 
constituencies from industry, government, and academia, and include alumni of our modeling and simulation programs as well as employers of our alumni.

Additionally, MSVE has established a student chapter of the Society for Modeling and Simulation International (SCS) at Old Dominion University and the 2013/2014 SCS President (Dr. John Sokolowski) is one of our faculty, holds the VMASC Executive Director position, and participates on the MSVE IAB. Dr. Sokolowski is also our first Ph.D. graduate in M\&S from 2003.

\section{EducAtional OBJECTIVES ReVIEW PROCESS}

The review and revision process for the PEOs is shown in Figure 1. Since the Student Outcomes lead to the achievement of the Program Educational Objectives (PEOs), the evaluation of the Program Educational Objectives is expected to be tied to the evaluation of the Student Outcomes. Likewise, the achievement or lack thereof for Student Outcomes evidenced by Program Evaluation Results (PERs) will contribute to the determination of the enhancements / revisions, if any, that would need to be made to the PEOs.

At its inception, the M\&SE program was designed to meet ABET accreditation standards, and the process and curriculum was first published in Leathrum and Mielke (2011). As part of this process, industry constituents and faculty were surveyed to develop the initial set of PEOs. Since then, periodic reviews have followed the process in Figure 1. Note that Figure 1 is a subset of the MSVE systematic continuous improvement process described in Criterion 4 and expanded in Table 3.

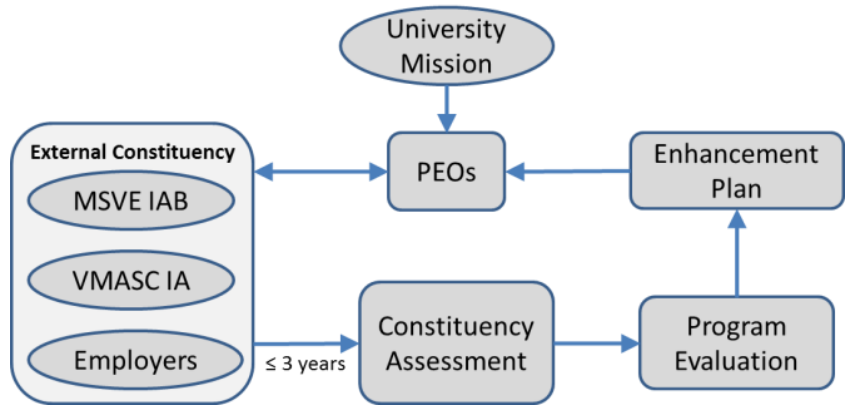

Figure 1. PEO Relevance Review and Assessment for the BS in M\&SE Program

The Department reviews, assesses, and revises, if necessary, the PEOs every three years or as needed to coincide with the alumni/employer survey. The next cycle will begin in the Fall semester 2016 and culminate in Spring 2017. However, PERs and the Program Enhancement Plans (PEPs) may trigger earlier reviews of the PEOs. As seen in the figure, PEOs are ensured to be consistent with the University Mission and are provided to our External Constituency for review. This is accomplished by formally presenting them for discussion in MSVE IAB meetings and Employer Surveys while informally presenting them to VMASC Industry Association (IA) members. M\&SE PEOs were last formally presented to the MSVE IAB on November 2013 and entered into the minutes where any additional feedback was solicited. The MSVE IAB provided feedback to consider a potential update to the Department Vision that was presented to the MSVE Faculty during the January 2014 department meeting at which time the faculty recommended no change to the Department Vision. The minutes of the November IAB meeting was formally approved at the April 2014 IAB meeting. The PEOs were also formally assessed via an employer survey and the results presented in our ABET Self-Study Report. Informal presentations of the PEOs were made on November 14, 2013 to the VMASC IA at their general meeting which also included members of the MSVE IAB. Feedback from this informal setting would be received directly or from MSVE IAB members. Members did not provide suggested updates to the PEOs.

The efforts described above results in the collection of data for Constituency Assessment (this activity is shown in Figure 1) and the follow-on Program Evaluation activity conducted by the MSVE Assessment Committee. The MSVE Assessment Committee is a subset of the MSVE Undergraduate Committee which consists of all MSVE faculty teaching core MSVE undergraduate courses plus the Academic Advisor and Program Manager (AAPM). The MSVE Assessment Committee produces PERs that identify any gaps, strengths and weaknesses in the program that are then evaluated against the costs and benefits to the department to recommend actions in the PEP. The Department Chair participates in the Program Evaluation activity and approves any actions requiring financial resources. PEP actions are discussed with associated faculty by the Chair and other assessment committee members as needed and also presented to the general MSVE Faculty for feedback and final update to the PEP. To close the loop, all instituted actions from the PEP are evaluated during subsequent cycles until Constituency Assessment shows evidence of satisfactory improvement and the action is then closed. The MSVE Department intends to assess attainment (even though not required by ABET) and the relevance of PEOs on a tri-annual cycle.

\section{STUDENT OUTCOMES}

The Department adopted the 11 (a thru k) Student Outcomes for the ABET Engineering Accreditation Commission (EAC) General Engineering program. M\&SE Student Outcomes A1-A11 map one-to-one with the ABET Criterion 3 outcomes a-k with little or no change. Outcomes P1 through P-9 are based on program-specific outcomes that MSVE Faculty created to unambiguously define the achievements expected from students that are specific to a modeling and simulation engineering program and discipline. 
The Table 1 shows the mapping of our 3 program educational objectives to the supporting program outcomes (ABET and discipline-specific).

Table 1. Relationship of PEOs to Student Outcomes

\begin{tabular}{|c|c|}
\hline PEOs & Supporting SOs \\
\hline $\begin{array}{l}\text { a) Established themselves as } \\
\text { practicing professionals in modeling and } \\
\text { simulation engineering or related areas } \\
\text { or have engaged in graduate study; }\end{array}$ & $\begin{array}{l}\text { a, b, c, e, i, k, P-1, } \\
\text { P-2, P-3, P-4, P-5, } \\
\text { P-6, P-7, P-8, P-9 }\end{array}$ \\
\hline $\begin{array}{l}\text { b) Demonstrated their ability to work } \\
\text { successfully as members of a } \\
\text { professional team and to function } \\
\text { effectively as responsible professionals; }\end{array}$ & $\begin{array}{l}\mathrm{b}, \mathrm{c}, \mathrm{d}, \mathrm{f}, \mathrm{g}, \mathrm{h}, \mathrm{j}, \mathrm{k}, \\
\text { P-1, P-4, P-6, P-7, } \\
\text { P-8, P-9 }\end{array}$ \\
\hline $\begin{array}{l}\text { c) Demonstrated their ability to adapt } \\
\text { to changing situations, evolving } \\
\text { technologies, and new career challenges. }\end{array}$ & $\begin{array}{l}\text { f, h, i, j, k, P-2, P- } \\
4, \text { P-5, P-8, P-9 }\end{array}$ \\
\hline
\end{tabular}

We created a mapping between the student outcomes and the supporting courses along with the assessment year for particular SOs. The mapping highlights courses that contributed to the achievement of the student outcome and also was used for assessment. Our ABET Course Syllabi identifies for each course additional SOs that a particular course may cover but was not assessed during this 2-year cycle.

The mapping also shows the distribution of the assessment of SOs over odd and even years of the 2-year cycle. In this manner, assessment is performed annually and SOs are evaluated annually utilizing a 2-year cycle of assessment data.

A possible action from a Program Enhancement Plan (PEP) would be to alter or increase the coverage of a particular SO, recommend an update or change in the specific topic area/performance indicator being assessed for a particular SO, or request an update to the rubric utilized to help evaluate the extent to which an SO was being achieved.

\section{ASSESSMENT}

In making decisions regarding program improvements, the Department primarily uses results of assessment of the attainment (even though not requested by ABET) and the relevance of program educational objectives (Criteria 2) and the results of assessment of the attainment of student outcomes (Criteria 3). The Department also uses IAB reviews, rating of courses by seniors via exit interviews/surveys, and additional information provided in employer and alumni surveys to improve our curriculum to meet our PEOs and SOs.

The assessment of student outcomes is carried out using the following assessment processes:

- Courses (exam questions, homework questions, projects, peer evaluations)

- Faculty Course Portfolio
- Senior Exit Interview

- Senior Exit Survey

- Alumni Survey

- Employer Survey

Assessment instruments for all these processes were identified / developed, approved by faculty committees and MSVE Faculty, and utilized during the MSVE systematic 2year-assessment-data-cycle system as part of the faculty's commitment to continuous improvement. The evaluation of SOs are performed annually on the previous 2 years of assessment data and the records of 2-year cycle evaluation results / actions stored in the University's assessment management system called WEAVE. Assessment instruments and associated data from the utilization of these instruments are termed Student Learning Measures (SLMs).

Documentation will be provided for each instrument and SLM primarily in the form of reports and where appropriate sample student work. The majority of documentation is for the course level assessment of student outcomes and faculty course portfolios. The course level outcomes are available from Fall 2012 to Spring 2014. Pilot data were collected in Spring 2012 to evaluate the appropriateness of assessment instruments and these instruments were discussed and utilized by MSVE Faculty for the 2-year assessment cycle under review. In addition, faculty teaching portfolios are available as part of the Department's Faculty Teaching, Scholarship \& Service Evaluation process, and contain a portfolio for each course (course portfolio) including instructional material and handouts. Samples of student work for assessed assignments are also included.

The M\&SE Program SO Rubrics identified four levels of performance for each performance indicator: Unacceptable, Marginal, Good, Excellent. MSVE Faculty were charged with mapping each course assessment instrument used to the performance levels given the guidelines of performance in the associated outcome rubric. Each SO rubric identified topics and/or performance indicators along with guidelines that allowed faculty a consistent way of gauging the extent to which each topic/indicator was achieved. Course faculty mapped the achieved performance level for each student learning measure (SLM) to a quantifiable range of points for the categories / levels of performance for a given instrument. Then, the percentages of students performing at each of the levels were identified for each SLM in each course. This information was documented in a course level Outcome Assessment Report (OAR) for each assessed course for each year in our 2-year cycle. Utilizing course level SLMs, the Performance Target over the courses assessed is to achieve a Student Outcome Category Average (SOCA) of 3.2 with an average of $75 \%$ of students in the Good or Excellent range over all courses assessed for a particular SO. 
Table 2. M\&SE Student Learning Measures (SLMs) and Performance Targets

\begin{tabular}{|c|c|c|c|c|}
\hline SLM & $\begin{array}{l}\text { Assessment } \\
\text { Instrument }\end{array}$ & Assessment Type & Frequency & Performance Level / Metric \\
\hline \multirow{4}{*}{ Courses } & Exam Questions & $\begin{array}{l}\text { Direct / Objective } \\
\text { / Quantitative }\end{array}$ & Semester & \multirow{4}{*}{$\begin{array}{l}\text { The M\&SE Program Rubrics identified four levels of } \\
\text { performance for each performance indicator: } \\
\text { Unacceptable (value of } 1.0 \text { ), Marginal }(2.0) \text {, Good } \\
\text { (3.0), and Excellent (4.0). Our Performance Target } \\
\text { is to achieve a Student Outcome Category } \\
\text { Average (SOCA) quantified score of } 3.2 \text { out of } 4.0 \\
\text { with an average of } 75 \% \text { of students in the Good or } \\
\text { Excellent range over all courses assessed for a } \\
\text { particular SO. }\end{array}$} \\
\hline & Homework & Direct & Semester & \\
\hline & Projects & Direct & Semester & \\
\hline & Peer Evaluations & $\begin{array}{l}\text { Direct / Subjective } \\
\text { / Quantitative }\end{array}$ & Semester & \\
\hline $\begin{array}{l}\text { Faculty } \\
\text { Course } \\
\text { Portfolio }\end{array}$ & $\begin{array}{c}\text { MSVE Faculty } \\
\text { Teaching } \\
\text { Portfolio and } \\
\text { Faculty Teaching } \\
\text { Portfolio } \\
\text { Evaluation } \\
\end{array}$ & $\begin{array}{l}\text { Indirect / Subjective } \\
\text { / Qualitative }\end{array}$ & $\begin{array}{l}\text { Annually \& } \\
\text { Tri- } \\
\text { Annually }\end{array}$ & $\begin{array}{l}\text { Performance Target is for individual faculty to } \\
\text { achieve an overall rating of Agree or Strongly Agree. }\end{array}$ \\
\hline $\begin{array}{l}\text { Senior Exit } \\
\text { Interview }\end{array}$ & Focus Group & $\begin{array}{l}\text { Indirect / Subjective } \\
\text { / Qualitative }\end{array}$ & $\begin{array}{l}\text { Annually } \\
\text { Spring } \\
\text { Semester }\end{array}$ & $\begin{array}{l}\text { Issues are identified as to their meaningfulness based } \\
\text { on the amount of general consensus reached for a } \\
\text { particular item. Interview notes are then utilized } \\
\text { within the continuous improvement process. }\end{array}$ \\
\hline $\begin{array}{l}\text { Senior Exit } \\
\text { Survey }\end{array}$ & $\begin{array}{l}\text { Electronic } \\
\text { Survey }\end{array}$ & $\begin{array}{l}\text { Indirect / Subjective } \\
\text { / Quantitative }\end{array}$ & $\begin{array}{l}\text { Semester } \\
\text { Upon } \\
\text { Graduation }\end{array}$ & $\begin{array}{l}\text { Students are surveyed on a Likert-scale and open } \\
\text { ended questions on SO achievement, courses, MSVE } \\
\text { Faculty, advising, employment, student organizations, } \\
\text { and strengths and weaknesses of the program. } \\
\text { Our Performance Target is to achieve to achieve a } \\
\text { SOCA score of } 3.2 \text { out of } 4.0 \text { with an average of } \\
75 \% \text { of students in the Agree or Strongly Agree / } \\
\text { Good or Excellent ranges. Employment targets are } \\
\text { for our students to be either employed competitively } \\
\text { in the engineering industry or attending graduate } \\
\text { school. }\end{array}$ \\
\hline $\begin{array}{l}\text { Alumni } \\
\text { Survey }\end{array}$ & Emailed Survey & $\begin{array}{l}\text { Indirect / Subjective } \\
\text { / Quantitative }\end{array}$ & $\leq 3$ Years & $\begin{array}{l}\text { Students are asked Likert-scaled questions on } \\
\text { employment, preparation, overall program } \\
\text { impression, and SO achievement. } \\
\text { Our Performance Target is to achieve a SOCA } \\
\text { score of } 3.2 \text { out of } 4.0 \text { with an average of } 75 \% \text { of } \\
\text { students in the Agree or Strongly Agree range. } \\
\text { Employment targets are for our students to be either } \\
\text { employed competitively in the engineering industry } \\
\text { or attending graduate school. }\end{array}$ \\
\hline $\begin{array}{l}\text { Employer } \\
\text { Survey }\end{array}$ & Emailed Survey & $\begin{array}{l}\text { Indirect / Subjective } \\
\text { / Quantitative }\end{array}$ & $\leq 3$ Years & $\begin{array}{l}\text { Employers are asked Likert-scale questions on } \\
\text { employment, PEOs, and SO achievement. } \\
\text { Our Performance Target is to achieve a SOCA } \\
\text { score of } 3.2 \text { out of } 4.0 \text { with an average of } 75 \% \text { in } \\
\text { the Agree or Strongly Agree range. }\end{array}$ \\
\hline
\end{tabular}

$1^{\text {th }}$ LACCEI Annual International Conference: "Engineering Education Facing the Grand Challenges, What Are We Doing?" July 29-31, 2015, Santo Domingo, Dominican Republic 
These targets are subject to change as part of our continuing review process and as an action resulting from Program Enhancement Plans. Table 2 shows the various SLMs utilized in our assessment processes.

Using the results of our systematic assessment of Criterion 2 and 3 and other inputs described above, the MSVE Assessment Committee evaluates all PEOs and SOs then recommends appropriate actions. Any changes to the curriculum are implemented following the approval by the MSVE Faculty. There is no specific cycle for implementation of the changes and it is done on a continuous basis at the earliest opportunity. However, assessment and evaluation of the effects of any changes will fall into MSVE regularly established annual 2-year data cycle reviews.

\section{CONTINUOUS IMPROVEMENT}

In this section we discuss our systematic continuous improvement process with its actors and inputs, the 2-year data cycle for annual Program Enhancement Plans (PEPs) with identified actions, results of initial changes made (closing the loop), and future program improvement plans

Assessment of the achievement of Student Outcomes is done on an annual basis using the SLM instruments discussed above. The analysis of the assessment is done by the Chair, Frederic (Rick) McKenzie, of the MSVE Department and the MSVE Assessment Committee: Roland Mielke (Chair of the Assessment Committee and former chair of the MSVE Department), James Leathrum (Chief Departmental Advisor), ManWo Ng (MSVE Assistant Professor), and Mr. Trey Mayo (AAPM). The results of the assessment and recommended actions are presented to the faculty at faculty meetings and / or yearly retreats. Upon approval by the MSVE Department Faculty, the Department implements the proposed actions by the committee. The first column in Table 3 shows the assessment and evaluation activities in our continuous improvement process.

Particulars about the review and update of PEOs were illustrated in Figure 1 and discussed. If there were updates to our PEOs, the Program Evaluation activity would determine what effects any updates would have and identify any necessary changes to SOs that would result from an updated PEO. Additionally, it is possible that program evaluations suggest a change to PEOs that would result in an action within the annual Program Enhancement Plan (PEP).
Table 3. M\&SE Systematic Assessment Processes and Inputs

\begin{tabular}{|c|c|c|c|c|}
\hline $\begin{array}{l}\text { Process / } \\
\text { Activity }\end{array}$ & Actor & Input & Frequency & Output \\
\hline \multirow{4}{*}{$\begin{array}{c}\text { Constituency } \\
\text { Assessment }\end{array}$} & \multirow{4}{*}{$\begin{array}{c}\text { MSVE } \\
\text { Assessment } \\
\text { Committee, } \\
\text { MSVE Faculty }\end{array}$} & $\begin{array}{l}\text { Alumni } \\
\text { Survey }\end{array}$ & $\begin{array}{c}\text { Tri- } \\
\text { Annually }\end{array}$ & \multirow{4}{*}{$\begin{array}{l}\text { Survey } \\
\text { Summaries, } \\
\text { Revalidated } \\
\text { or Revised } \\
\text { PEOs, } \\
\text { MSVE IAB } \\
\text { and Informal } \\
\text { Feedback }\end{array}$} \\
\hline & & $\begin{array}{c}\text { Employer } \\
\text { Survey }\end{array}$ & $\begin{array}{c}\text { Tri- } \\
\text { Annually }\end{array}$ & \\
\hline & & $\begin{array}{c}\text { IAB } \\
\text { Minutes }\end{array}$ & $\begin{array}{c}\text { Tri- } \\
\text { Annually }\end{array}$ & \\
\hline & & $\begin{array}{c}\text { Informal } \\
\text { Feedback } \\
\text { (VMASC } \\
\text { IA } \\
\text { and Others) }\end{array}$ & $\begin{array}{l}\text { Contin- } \\
\text { uous }\end{array}$ & \\
\hline $\begin{array}{c}\text { Student } \\
\text { Outcome } \\
\text { Assessment }\end{array}$ & $\begin{array}{c}\text { MSVE Faculty, } \\
\text { MSVE } \\
\text { Assessment } \\
\text { Committee }\end{array}$ & $\begin{array}{c}\text { SO } \\
\text { Rubrics, } \\
\text { Course } \\
\text { SLMs }\end{array}$ & Annually & $\begin{array}{l}\text { Cross Course } \\
\text { Assessments, } \\
\text { Outcome } \\
\text { Assessment } \\
\text { Reports } \\
\text { (OARs), } \\
\text { PERs } \\
\end{array}$ \\
\hline \multirow[b]{2}{*}{$\begin{array}{c}\text { Program } \\
\text { Assessment }\end{array}$} & $\begin{array}{l}\text { Teaching } \\
\text { Portfolio } \\
\text { Review } \\
\text { Committee }\end{array}$ & $\begin{array}{c}\text { Faculty } \\
\text { Teaching } \\
\text { Portfolios }\end{array}$ & $\begin{array}{l}\text { Annually, } \\
\text { Tri- } \\
\text { Annually }\end{array}$ & $\begin{array}{l}\text { Faculty } \\
\text { Teaching } \\
\text { Portfolio } \\
\text { Evaluation }\end{array}$ \\
\hline & $\begin{array}{c}\text { MSVE } \\
\text { Undergraduate } \\
\text { Committee, } \\
\text { MSVE } \\
\text { Assessment } \\
\text { Committee } \\
\end{array}$ & $\begin{array}{c}\text { WEAVE } \\
\text { Report, } \\
\text { Curriculum } \\
\text {, Policy, } \\
\text { Facility, } \\
\text { Resources }\end{array}$ & $\begin{array}{l}\text { Contin- } \\
\text { uous }\end{array}$ & $\begin{array}{l}\text { Current } \\
\text { Status }\end{array}$ \\
\hline $\begin{array}{c}\text { Program } \\
\text { Evaluation }\end{array}$ & $\begin{array}{c}\text { MSVE } \\
\text { Assessment } \\
\text { Committee, } \\
\text { Department } \\
\text { Chair }\end{array}$ & $\begin{array}{c}\text { Alumni } \\
\text { Survey } \\
\text { Summary, } \\
\text { Employer } \\
\text { Survey } \\
\text { Summary, } \\
\text { Revised } \\
\text { PEOs, } \\
\text { PERs, } \\
\text { Faculty } \\
\text { Teaching } \\
\text { Portfolio } \\
\text { Evaluation }\end{array}$ & $\begin{array}{l}\text { Annually } \\
\text { on Two- } \\
\text { Year Data }\end{array}$ & $\begin{array}{l}\text { PERs } \\
\text { Summary } \\
\text { with } \\
\text { identified } \\
\text { SO issues, } \\
\text { Program } \\
\text { Enhance- } \\
\text { ment Plan } \\
\text { (PEP) }\end{array}$ \\
\hline
\end{tabular}

For Student Outcome Assessment, each SO rubric identified topics and/or performance indicators along with guidelines that allowed faculty to gage the extent to which each topic/indicator was achieved. These achievable performance levels were used to map SLMs chosen from the educational options and strategies course faculty have at their discretion. A possible action in the PEP could be the recommendation to make changes to Educational \& Assessment Strategies that could affect educational practices 
and/or strategies for assessment; for example, a change in the SLM utilized for a particular SO.

The purpose of the Program Evaluation activity is for the MSVE Assessment Committee and the Department Chair to evaluate the results of the assessment activities (including Program Assessment) and determine if there are issues associated with PEOs or SOs. Issues are identified if established Performance Targets for particular SOs are not met. During the Program Evaluation process, the MSVE Assessment Committee determine if these issues identify any gaps, strengths or weaknesses in the program which need to result in recommended actions in the PEP. The Department Chair participates in the Program Evaluation process and approves any actions requiring financial resources. PEP actions are discussed with associated faculty by the Chair and other Assessment Committee members as needed and also presented to the general MSVE Faculty for feedback and final update to the PEP. To close the loop, all instituted actions from the PEP are evaluated during subsequent cycles until assessment data shows evidence of satisfactory improvement and the action is then closed.

Finally, other actions that may be in the PEP could address program organizational components such as curriculum, facilities, policy, faculty, and resources.

These actions proposed by the MSVE Assessment Committee will be presented to the MSVE Faculty at the MSVE Faculty Retreat at the beginning of the Fall semester. Upon approval, affected faculty will be asked to implement the actions during the Academic Year, if possible.

\section{ACKNOWLEDGMENT}

This effort is a culmination of a lot of work by all the faculty and staff in the ODU MSVE Department especially Dr. Roland Mielke, Mr. Trey Mayo, and Ms. Jayne Massey.

\section{REFERENCES}

[1] Rogers, R., "What Makes a Modeling and Simulation Professional: The Consensus View from One Workshop," Proceedings of the Winter Simulation Conference, Piscataway, NJ, 1997.

[2] Yurcik, W. and R. Silverman (2000), "The 1998 NSF Workshop on Teaching Simulation to Undergraduate Computer Science Majors," SCSC, Vancouver, Canada.

[3] Sarjoughian, H. S., and B.P. Zeigler, Towards Making Modeling \& Simulation into a Discipline, Western Multi-Conference, Phoenix AZ, Jan. 2001

[4] "Simulation-Based Engineering Science," Report of the National Science Foundation Blue Ribbon Panel on Simulation-Based Engineering Science, National Science Foundation, May 2006.

[5] Leathrum, J. and Mielke, R., "A Bachelor of Science in Modeling and Simulation Engineering", Proceedings of the International Symposium on Engineering Education and Education Technologies, Orlando, FL, July 19-22, 2011.

[6] Mielke, R., Leathrum, J., and McKenzie, F., "A Model for UniversityLevel Education in Modeling and Simulation", M\&S Journal, Vol. 6, No. 3, pp. 14-23, December 2011.
[7] Birta, L.G., "The Quest for the Modelling and Simulation Body of Knowledge," Proceedings of the Sixth Conference on Computer Simulation and Industry Applications, Tijuana, Mexico, 2003.

[8] Petty, M., "Modeling and Simulation Body of Knowledge Topics", in Certified Modeling \& Simulation Professional Program - Management Plan, Modeling and Simulation Professional Certification Commission, Version 1.0, June 12, 2009, from http://www.simprofessional.org.

[9] R. Mielke, J. Leathrum, and F. McKenzie, "Design of an ABETAccredited Undergraduate Modeling and Simulation Engineering Program," 2014 ABET Symposium, Pittsburgh, PA, April 3-4, 2014.

$1^{\text {th }}$ LACCEI Annual International Conference: "Engineering Education Facing the Grand Challenges, What Are We Doing?" July 29-31, 2015, Santo Domingo, Dominican Republic 